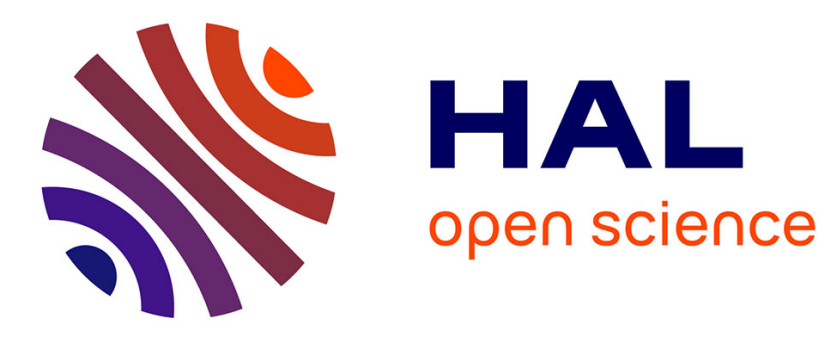

\title{
Are plants useful as accumulation indicators of metal bioavailability?
}

Esteban Remon, Jean Luc Bouchardon, Marina Le Guédard, Jean-Jacques

Bessoule, Cyrille Conord, Olivier Faure

\section{- To cite this version:}

Esteban Remon, Jean Luc Bouchardon, Marina Le Guédard, Jean-Jacques Bessoule, Cyrille Conord, et al.. Are plants useful as accumulation indicators of metal bioavailability? Environmental Pollution, 2013, 175, pp.1-7. 10.1016/j.envpol.2012.12.015 . hal-00771221

\section{HAL Id: hal-00771221 https://hal.science/hal-00771221}

Submitted on 8 Jan 2013

HAL is a multi-disciplinary open access archive for the deposit and dissemination of scientific research documents, whether they are published or not. The documents may come from teaching and research institutions in France or abroad, or from public or private research centers.
L'archive ouverte pluridisciplinaire HAL, est destinée au dépôt et à la diffusion de documents scientifiques de niveau recherche, publiés ou non, émanant des établissements d'enseignement et de recherche français ou étrangers, des laboratoires publics ou privés. 


\section{Are plants useful as accumulation indicators of metal bioavailabity?}

E. Remon ${ }^{\text {c,h }}$, J-L. Bouchardon ${ }^{\mathrm{a}, \mathrm{b}, \mathrm{c}}$, M. Le Guédard ${ }^{\mathrm{e}, \mathrm{fg}}, \mathrm{J}-\mathrm{J}$. Bessoule $^{\mathrm{e}, \mathrm{fg}, \mathrm{g}}$,

${ }^{a}$ Université de Lyon, F-69362 Lyon Cedex, France

${ }^{\mathrm{b}}$ CNRS, UMR-5600 EVS, F-69362 Lyon Cedex, France

${ }^{\mathrm{c}}$ Ecole Nationale Supérieure des Mines de Saint-Etienne, Département SPIN, Laboratoire

10 GéoSciences \& Environnement, 158 cours Fauriel, F-42023, Saint Etienne Cedex 2, France

${ }^{\mathrm{d}}$ Université Jean Monnet, F-42023 Saint-Etienne Cedex 2, France.

${ }^{\mathrm{e}}$ CNRS, Laboratoire de Biogenèse Membranaire, UMR-5200, F-33883

${ }^{\mathrm{f}}$ Univ. Bordeaux, Laboratoire de Biogenèse Membranaire, UMR-5200, F-33883

${ }^{\mathrm{g}}$ LEB Aquitaine Transfert-ADERA, F-33883 Villenave d'Ornon Cedex, France

${ }^{\mathrm{h}}$ Present adress : MEP Corrèze, F-19162 Neuvic, France

* Corresponding author: Ecole Nationale Supérieure des Mines de Saint-Etienne,

20 Département SPIN, UMR-5600, Laboratoire GéoSciences \& Environnement (GSE), 158 cours Fauriel, F-42023 St-Etienne Cedex 2, France

Tel: (33) (0) 477420206

E-mail address: ofaure@emse.fr 


\begin{abstract}
The use of accumulation bioindicator to assess metal bioavailability has mainly concerned individual species. This work addresses this issue at the plant community level. Metal content within different species from plant communities found at three contaminated and one uncontaminated site were compared. Results showed that for two contaminated sites, leaf metals concentrations were comparable to those in plants from control site, i.e. approx $(\mathrm{mg} / \mathrm{kg}) 0.1 \mathrm{Cd}, 0.2 \mathrm{Cr}, 9.2 \mathrm{Cu}, 1.8 \mathrm{Ni}, 0.5 \mathrm{~Pb}$ and $42 \mathrm{Zn}$. Only plants from the third site showed higher metal contents, ranging from 1.5- to 8-fold those of the control community.

35 This contrasted with ammonium acetate-EDTA extractions, which indicated a very high "availability" of metals at the three sites, as compared to the control site. Thus, metal content in plant communities provided accurate information on actual transfer toward the ensemble of vegetation, which could be used to establish site-specific "fingerprints" of metal bioavailability.
\end{abstract}

Capsule: Plant communities as accumulation bioindicators of trace metal bioavailability in contaminated soils.

Keywords: Soil contamination; Phytoavailability; Bioindication; Metallurgical landfill 


\section{Introduction}

During the last two decades there has been an increasing awareness of the potential adverse effects of soil pollution by trace metals (Adriano, 2001). As a consequence, assessing soil metal contamination is today of major interest for governments and regulators who are concerned with public health and sustainable development policies (Fairbrother et al., 2007). A number of standardized procedures have been developed for rapid, precise and reliable measurement of total metal content in soils (AFNOR, 1994, 2001, 2002). Nevertheless, it is obvious that metal toxicity in soils depends on complex geochemical and biological interactions (van Gestel, 2008) that cannot be anticipated by the sole knowledge of total content. Thus, it is widely admitted that simply measuring total metal concentrations does not provide enough information for an accurate risk assessment (McLaughlin et al., 2000).

In fact, when studying metal-enriched soils, one of the main questions is whether contaminants can be transferred to living organisms, i.e. whether these metals are bioavailable (Schekel et al., 2009). Indeed, a number of chemical extraction methods have been developed for assessing the likelihood of a metal's bioavailability. Basically, these methods use more or

60 less strong extractants, either in single step protocols (Beckett, 1989, Houba et al., 1990, 1996) or in sequential extraction procedures (Tessier et al., 1989, Quevauvillier et al., 1997). However, although these approaches have brought significant knowledge about interactions between metals and soil components, they seldom can predict the fraction of metal actually interacting with living organisms (McLaughlin et al., 2000, van Gestel, 2008, Wilson et al., 2009, Mourier et al., 2011). Consequently, development of supplemental methods to evaluate the bioavailability of metals remains necessary (Moreno-Jimenez et al., 2011). From this standpoint, the use of bioindicators (Pérès et al., 2011, Le Guédard et al., 2012) is a simple and efficient complementary approach to chemical extraction procedures.

Bioindicators are organisms that help study the level ("accumulation bioindicators") 
and/or impact ("effect bioindicators") of pollutants in the environment. Measuring the content of metals or other toxic compounds in these living organisms is of great interest to assess the actual bioavailability of contaminants. During the last decade, a few animal species have been shown to be efficient accumulation indicators of soil contamination by trace metals, e.g. the snail Helix aspersa (Gomot de Valfleury and Pihan, 2000), earthworm Eisenia foetida

75 (Nahmani et al., 2007) and collembolan Proistoma minuta (Nursita et al., 2009). Likewise, the use of plants as accumulation indicators is a rather old concept, and several species are now considered as good bioindicators of soil contamination, e.g. Taraxacum officinale (Kuleff and Djingova, 1984, Simon et al., 1996), Capsella bursa-pastoris (Aksoy et al., 1999) or Populus alba (Madejon et al., 2004). In fact, when compared to animal bioindicators, plants have a number of advantages. They are sessile organisms and their mineral nutrition is closely dependant on the soil characteristics. They are ubiquitous organisms colonizing virtually all terrestrial environments, even those that are highly contaminated. Their classification is well established and their taxonomic recognition is often unproblematic. Lastly, plants are easy to collect and generally produce enough biomass to allow chemical analyses. However, using a single plant species to assess metal bioavailability is open to criticism (Mertens et al., 2005). This is mainly because metal content in plants can be both element- and species-dependent (Baker, 1981, Harada and Hatanaka, 2000, Broadley et al., 2001). Thus the indication of metal bioavailability by plants needs further investigation before being adopted in routine assessments of soil quality.

In this work, we postulated that performing metal analyses for communities of plants, rather than a single species evaluation, could be a more comprehensive and effective method to judge contaminated soils with respect to metal bioavailability. To assess this approach, metal concentrations in a set of different plant species representative of local plant communities from three contaminated sites, and an uncontaminated control site, were 
measured. Metal bioavailability, as estimated by phytoaccumulation data, was compared with "metal potential mobility" determined by a chemical extraction procedure. Results are discussed in relation to the concept of bioavailability in the area of risk assessment for contaminated soils.

\section{Materials and method}

\subsection{Site descriptions}

Three former metallurgical landfills of varying ages were studied. The first one ("Dor" site) was situated near Saint-Etienne (Loire, France). This foundry waste site extended over approximately 2 ha with a dense plant cover with many trees and bushes. Although there was not much historical data on this site, according to the tree sizes and the vegetation cover we assumed it had been abandoned for at least 60 years. The second landfill ("Lay" site) was located in the same commune, but about $5 \mathrm{~km}$ away. It had been used from about 1916 to the beginning of the sixties and was subsequently abandoned. The Lay's entire area extended over 4.5 ha with a relatively even vegetation cover with grasses, shrubs and trees (Remon et 110 al., 2005). The third landfill ("Usi” site) was located near Lyon (Rhône, France), about 30 km away from the two other sites. The landfill was just behind a steel and iron factory which was still active. The Usi landfill had been used from about 1850 to 2001, and extended over nearly 15 ha. The vegetation cover on this landfill was not homogeneous: some areas were still periodically disturbed by heavy vehicle traffic and were scarcely colonized by plants or not at

115 all. However, there were other undisturbed areas (perhaps for several years) that showed greater plant diversity with relatively homogeneous vegetation cover, mainly constituted of ruderal and pioneer species.

In addition to the three metallurgical landfills, an uncontaminated natural site (Nat site) was included in the study, as a soil control. 


\subsection{Soil analysis}

For each site, 9 to 19 random soil samples were collected at a depth of 0 to $20 \mathrm{~cm}$, in vegetated places. Samples were dried at $60^{\circ} \mathrm{C}$ for $48 \mathrm{~h}$ and sieved to $2 \mathrm{~mm}$ before analysis.

Measurements of $\mathrm{pH}$ values were carried out in deionised water with a soil/water ratio

125 of 1:2 following the NF ISO 10390 procedure (AFNOR, 2005). Metal extraction was conducted with aqua regia according to the NF X 31-151 procedure (AFNOR, 1994) for "pseudo-total fraction" (i.e. considering metals in silicates are not leachable), and with ammonium acetate-EDTA according to the NF X 31-120 procedure (AFNOR, 2003) for "potentially available fraction".

130 Concentrations of metals in various extracts were measured by inductively coupled plasma optical emission spectrometry (ICP-OES) using a Horiba Jobin-Yvon apparatus.

\subsection{Plant analysis}

For each site studied, a botanical survey of the plant community was carried out and the

1358 to 10 most abundant plant species were identified (Tab. I). For the Usi site, only undisturbed areas, with an homogeneous plant cover, were studied. Leaf samples of each species were collected from 6 to 10 randomly chosen locations over the study areas, resulting in a total of 48 to 90 leaf samples from each site. Plant sampling was performed in the beginning of June.

Leaf samples were thoroughly washed in tap water and rinsed with distilled water. They

140 were then dried at $40^{\circ} \mathrm{C}$ to constant weight and ground up to pass through a $2 \mathrm{~mm}$ sieve. Metal extraction was effectuated by digestion using hot $\mathrm{HNO}_{3}$, according to Zarcinas et al. (1987). Metal concentrations in the extracts were measured by ICP-OES.

\subsection{Accuracy and quality control of metal analysis}


The detection limits for metal analysis by ICP-OES were 0.06, 0.14, 1.17, 2.05, 2.38 and $15.51 \mu \mathrm{g}^{-1}$ for $\mathrm{Zn}, \mathrm{Cd}, \mathrm{Cr}, \mathrm{Cu}, \mathrm{Pb}$ and $\mathrm{Ni}$, respectively. The analytical precision was checked by measuring in triplicate about $20 \%$ of the samples. The relative standard deviation routinely was between 1 and $8 \%$, and never higher than $10 \%$.

For the quality assurance of soil analysis for total metals, certified reference soils NCS

150 DC 73323 and 73006 from the China National Analysis Center for Iron and Steel were used. They were also included in the batch of samples submitted to aquae regia extraction. Average recoveries ( $\mathrm{n}=6)$ were $83,73,76,85,104$ and $99 \%$ for $\mathrm{Zn}, \mathrm{Cd}, \mathrm{Cr}, \mathrm{Cu}, \mathrm{Pb}$ and $\mathrm{Ni}$, respectively.

For the quality assurance of plant analysis, the certified reference CTA-OTL-1 (Oriental

155 Tobacco Leaves from the Bulgarian Institute for Plant Protection) was employed. Average recoveries (n=6) were 98, 87, 110, 97, 106 and $103 \%$ for $\mathrm{Zn}, \mathrm{Cd}, \mathrm{Cr}, \mathrm{Cu}, \mathrm{Pb}$ and $\mathrm{Ni}$, respectively.

\subsection{Statistical analysis}

Because of the non-normal distributions of both metal contents in soils and in plants, we used the median and the median absolute deviation (MAD) as descriptors of the central tendency and dispersion of data distributions. Inter-group comparisons were performed using the distribution-free Kruskall-Wallis test. Post-hoc comparisons were done, when necessary, by pair wise Wilcoxon rank sum tests using the Holm's p-value-adjustment method. All

165 calculations were performed using the R 2.13.0 program (R Development Core Team, 2010). Differences were considered significant if $p<0.05$.

\section{Results}

3.1. "Pseudo-total" and "potentially available" metal concentrations in metallurgical soils 
Table II presents pH values and "pseudo-total" metal contents of the soils studied. An overview of these results show that a first clear-cut difference between metallurgical and natural soils resided in soil $\mathrm{pH}$. Median values ranged between 7.9 and 8.3 for the metallurgical landfills, in other words "moderately alkaline". It was 3.9 for the natural control soil, or "extremely acidic". Evidently, as expected, soils from metallurgical landfills had 175 much higher metal contents than the natural soil. This was particularly noticeable for $\mathrm{Ni}, \mathrm{Cr}$ and $\mathrm{Cu}$ whose median concentrations were respectively 14- to 71-fold, 10- to 54-fold and 8to 26 -fold higher in metallurgical soils than in the control. Although to a lesser extent, soils from metallurgical landfills were also clearly contaminated with $\mathrm{Pb}$ and $\mathrm{Zn}$ (median levels respectively 4.5 - to 15 -fold and 2 - to 10 -fold higher than in the natural soil). For Cd, only the

180 Usi site showed a very high contamination, while the Dor and Lay sites were not significantly different from the control, despite a few extreme values in some instances.

Results presented in Table II also show that "pseudo-total" metal contents in metallurgical soils were highly heterogeneous, as indicated by the MAD values which were always very close or even higher than the medians. This high variability, combined with the 185 relatively low number of samples collected on each site ( $n=12$ to 19$)$ and the use of distribution-free statistics, makes it difficult to determine if significant differences exist between the three metallurgical sites. Nevertheless the Lay site had overall lower metal content than the Dor and Usi sites. Furthermore, at least for $\mathrm{Cr}$ and Ni these differences were statistically significant. Likewise, the Usi site had significantly higher $\mathrm{Cd}$ and $\mathrm{Cu}$ levels than 190 the Dor and Lay sites. It had also a higher Zn content, but this divergence was only significant in comparison with the Lay site.

When "potentially available" metal contents (ammonium acetate-EDTA extractable fractions) were considered, the patterns of contamination were slightly altered (Tab. III). Despite the very high "pseudo-total" metal concentrations in the metallurgical soils, their 
ammonium acetate-EDTA extractable metal fractions were relatively low and, by comparison with the Nat site no significant difference was evidenced for $\mathrm{Cd}, \mathrm{Cr}$ and $\mathrm{Ni}$. In fact, only $\mathrm{Cu}$ and $\mathrm{Zn}$ were significantly higher in the three metallurgical soils, with levels respectively 7 - to 10-fold and 3- to 26-fold those of the natural site. For Pb, only the Lay site showed significantly higher extractable levels than the control site.

Comparisons between the three metallurgical soils (Tab. III) confirmed the trend previously observed for pseudo-total contents, indicating that the Usi site had overall higher amounts of available $\mathrm{Cd}, \mathrm{Cu}$ and $\mathrm{Zn}$. However, this difference was not statistically significant for $\mathrm{Cu}$. They also confirmed the great variability in extractable metal content as shown by the high values for MAD.

\subsection{Metal accumulation by plants}

Metal build up in plants was measured in leaf samples taken from the eight to ten most abundant species representative of the plant community observed on each site. For every selected species six to ten separate samples were collected at various locations over the sites 210 and analyzed for their metal content. Results are shown in figure 1.

As a general rule, leaf metal concentrations were relatively variable from one species to the next on a given site. This was particularly marked for the metallurgical landfills (Fig. 1, Dor, lay, Usi) where several species or groups of species were systematically separated from the others because of their different level in one or several metals. On the control site,

215 differences in metal content between species were less obvious (Fig. 1, Nat) and, except for $\mathrm{Cd}$, they were not statistically significant. Anyway, because of high inter-specific variability on contaminated sites, it was obvious that metal contents in an individual species couldn't be considered as representative of metal transfer toward the ensemble of vegetation as a whole.

To overcome this problem, the overall data of leaf metal contents in each species were 
pooled, to get an overview of metal transfer toward the plant community that was representative for each site. Results (Tab. IV) demonstrated that $\mathrm{Cr}$ content in the plant communities from de Dor, Lay and Usi sites were respectively 3.5-fold, 4.9-fold and 8.3-fold higher than that measured in the Nat site. Concerning the other metals, the plant communities from the "Dor" and "Lay" sites had not significantly higher contents than that of the "Nat" 225 site. Surprisingly, plant communities from the "Dor" and "Lay" sites had even significantly lower contents in $\mathrm{Cd}, \mathrm{Cu}, \mathrm{Pb}$ and $\mathrm{Zn}$ than the community from the natural uncontaminated site. Contrarily, plant community originated from the "Usi" site showed higher leaf concentrations in all metals but Cd (no significant difference with the Nat site) by comparison with the other studied sites. Aforementioned, this was particularly marked for Cr, but also for

230 Ni whose foliar concentration was about 6-fold higher in the plant community from the "Usi" site than in the community from the "Nat" site.

\section{Discussion}

The concept of metal bioavailability is rather complicated (Semple et al., 2004), and it is 235 virtually impossible to give it a clear and precise definition (Harmsen, 2007). Nonetheless, it is recognized today that bioavailability of metals in soil is a dynamic process (Peijnenburg et al., 1997, Lanno et al., 2004, Hodson et al., 2011) involving at least two distinct notions: the stability of thermodynamic equilibriums of metals at the water/solid phases interface, also called "bioaccessibility" or "environmental availability", and the physiological uptake 240 processes by target organisms, also called "bioavailability" or "environmental bioavailability" (Semple et al., 2004, Harmsen, 2007). Consequently, by integrating these two aspects, bioavailability can be operationally defined in terms of internal concentrations in living organisms, which is indeed an important issue in the area of risk assessment.

From this point of view, the aim of this work was to implement a methodology based on 
245 vegetation analysis, to assess metal bioavailability in contaminated soils. We assumed that analysing a set of differing plant species that were representative of the plant community at the study sites was an efficient strategy to obtain a general insight into metal bioavailability. To test this assumption we studied metal contents in soils (both in their "pseudo-total" and "extractable" forms) and in native vegetation from three metallurgical soils of various ages and one natural uncontaminated soil.

4.1. Metal concentrations in plant communities from foundry waste sites are not related to "pseudo-total" or "extractable" metals in soil

Determination of pseudo-total metals concentrations in soils from foundry waste dumps 255 showed they were highly contaminated, with metal levels ranging from 2- to 70-fold those measured in the control natural soil. Moreover, measurements of metal concentrations in the ammonium acetate-EDTA extractable fractions suggested that significant amounts of $\mathrm{Cu}, \mathrm{Zn}$ and, in a lesser extent $\mathrm{Pb}$, were highly "available". This was particularly noticeable for $\mathrm{Cu}$, whose extracted levels from the three metallurgical soils were even higher than total contents 260 normally found in unpolluted soils (median value in French soil approx. $13 \mathrm{mg} / \mathrm{kg}$, Baize, 2000). At the opposite end, despite very high pseudo-total concentrations, $\mathrm{Cd}, \mathrm{Cr}$ and $\mathrm{Ni}$ appeared to be no more "available" in the contaminated soils than in the natural soil. Thus, while results of aquae regia extractions indicated that the metal contaminated soils were clearly distinct from the natural soil because of their very high total metal contents, results of 265 ammonium acetate - EDTA extractions pointed out that only $\mathrm{Cu}, \mathrm{Zn}$ and $\mathrm{Pb}$ should pose a risk because of their high availability. Conversely, the very low content of $\mathrm{Cr}, \mathrm{Cd}$ and $\mathrm{Ni}$ in the extractable fractions suggested a very low availability of these metals and consequently, a low risk of transfer.

In view of these results we expected to find higher contents in $\mathrm{Cu}, \mathrm{Pb}$ and $\mathrm{Zn}$, and lower 
contents in $\mathrm{Cd}, \mathrm{Cr}$ and $\mathrm{Ni}$ in native plants colonizing metallurgical sites when compared to plants from natural site. However we did not find any clear relationship between leaf metal concentrations and soil's levels. For instance, plants from the Lay and Dor sites had significantly lower concentrations in $\mathrm{Cd}, \mathrm{Cu}, \mathrm{Pb}$ and $\mathrm{Zn}$ than those from the Nat site, albeit soils from metal waste dumps had significantly higher contents in these metals, both in total 275 and extractable fractions. Conversely, plants from metallurgical sites had significantly higher Cr contents than those from the natural site although $\mathrm{Cr}$ "availability", as estimated by ammonium acetate-EDTA extraction, was about the same in metallurgical and natural sites. Calculations of Kendall's $\tau$ coefficients correlation and associated p-values confirmed that, whatever the metal considered, there was no correlation neither between pseudo total metal contents in soils and metal contents in plants $(\tau<0.6 ; 0.17<p<0.62)$, nor between extractable metals in soils and metal in plants $(\tau<0.3 ; 0.37<\mathrm{p}<0.83)$. Thus, as already emphasized by a number of authors for different types of soil and contamination levels (McLaughlin et al., 2000, Murphy et al., 2000, Remon et al., 2005, van Gestel, 2008, Mourier et al., 2011, Lopes et al., 2012), these results confirm that neither "pseudo-total" soil concentrations nor "extractable" concentrations give enough information to foresee actual metal bioavailability on contaminated soils.

It must be noticed that extraction methods using chelating agents, such as EDTA or DTPA, were first developed (Viro, 1955, Lindsay and Norvell, 1978) to assess trace metal phytoavailability in agricultural unpolluted soils, with the aim of detecting potential micronutrient deficiencies. In others words, although these methods are routinely used for extracting metals from contaminated soils (Beckett, 1989, Ure, 1996), they have inherently not been designed to assess metals bioavailability in highly polluted matrices. 
4.2 Bioavailability of metals is lower in metallurgical industrial sites abandoned earlier

In this work we demonstrated that plant communities from the different study sites had differing metal content, suggesting differences in metal bioavailability. Comparison with the control Nat site lead to the conclusion that for the Dor and Lay sites the bioavailability of all metal but $\mathrm{Cr}$, is equal or lower than that observed on a natural uncontaminated soil. At the opposite end of the spectrum, for the Usi site the bioavailability of all metals, except for Cd, is 300 significantly higher. It is interesting to note that two out the three metal contaminated soils exhibit a low metal bioavailability while the third one, albeit of very similar origin, displays a high bioavailability. The goal of this work was not to study the underlying physico-chemical or biological differences between the sites considered, but simply to compare metal bioavailability. However, because the main differences between the three metallurgical

305 landfills reside in the age of the deposits and in the degree of development of the plant cover, we can suppose that both these factors may be related to the decrease in metal bioavailability. Actually, with time, beside the progressive leaching of the most labile metals, both weathering and plant development lead to an increase in clay and organic matter content, which are essential components controlling metal speciation. Thus, slow and progressive

310 pedogenic processes occurring on metallurgical waste deposits could play a key role in the decrease of "environmental availability" of metals. Also, it is known for a long time (Antonovics et al., 1971, Baker, 1987) that the selection pressure exerted by metals on contaminated sites may promote the emergence of tolerant races or ecotypes from normal populations (McNair, 1993, Remon et al., 2007). Although there are numerous strategies to 315 cope with excess metals (Baker, 1981), it is possible that the plant communities colonizing older metallurgical dumps have evolved towards a capacity to exclude metals, due to a natural increase in the number of excluder species (i.e species which maintain low leaf metal content under a wide range of soil concentrations, by preventing either metals uptake or their 
translocation from root to shoot). Thus, such a selection of excluder species would lead to a decrease in the "environmental bioavailability" of metals. Consequently, ageing and successional changes in plant communities (Wang et al., 2011) could promote a decrease in both environmental "availability" and "bioavailability", hence leading to a decrease in metal bioavailability as a whole.

4.3 Metals content in plant communities is a "chemical fingerprint" of metal bioavailability

For an evaluation of soil quality, it is important to have reference values (i.e. values for the metal content from plants growing in uncontaminated soil) to interpret field data. The concept of reference values for plant mineral content was first introduced by Höhne (1962) and Duvigneaud and Denaeyer-de Smet (1970) with respect to macronutrients contents in plants (Ca, Mg, N, P, K). This concept was brought a step further by Markert (1992) who proposed, by analogy to the "Reference Man" established by the International Commission on Radiological Protection, to define the "Reference Plant", i.e. average content of all the inorganic elements found in plants. Thus according to Markert (1992), the following values could be considered for leaf metal concentrations in plants from uncontaminated environment: $0.08 \mathrm{mg} \mathrm{kg}^{-1} \mathrm{Cd}, 1.50 \mathrm{mg} \mathrm{kg}^{-1} \mathrm{Cr}, 8.90 \mathrm{mg} \mathrm{kg}^{-1} \mathrm{Cu}, 1.50 \mathrm{mg} \mathrm{kg}^{-1} \mathrm{Ni}, 0.84 \mathrm{mg}$ $\mathrm{kg}^{-1} \mathrm{~Pb}$ and $40.60 \mathrm{mg} \mathrm{kg}^{-1} \mathrm{Zn}$. It is noteworthy that these values are in close agreement with those of Harada and Hatanaka (2000) suggested for Japanese plants. These reference values can thus be used to establish the baseline of the "chemical fingerprint" (Markert, 1992) for the native vegetation for any kind of soil.

To illustrate this approach, figure 2 shows the relative deviations (RD) in metals content of plants from the sites studied in this paper, in comparison with the Markert's "Reference Plant". Plants taken from the "Nat" site are very similar to the "Reference Plant", with relative deviations in terms of metal concentrations varying between -85 and $+50 \%$. Likewise, plants 
originating from the "Lay" and "Dor" sites are closely related to the "Reference Plant", with slightly lower or higher leaf metal levels $(-92 \%<\mathrm{RD}<+27 \%)$. This confirms that their metal bioavailability is low, and anyway not significantly higher than in a normal situation, despite very high total and extractable levels in soils. Conversely, plants from the "Usi" site show systematically higher metal contents than the "Reference Plant", resulting in positive values of the $\mathrm{RD}(+22 \%<\mathrm{RD}<550+\%)$ for all the analyzed metals. This is particularly noticeable for $\mathrm{Ni}$, whose relative leaf concentration is $550 \%$ with respect to "Reference Plant". This clearly confirms that metal bioavailability is dramatically higher in the "Usi" soil than in normal uncontaminated soil.

\section{Conclusion}

There is no doubt today (AFNOR, 2008) that there is a need for developing complementary methods to chemical extraction procedures, which could be used to monitor soil's quality with respect to metal bioavailability. In this context we hypothesized that plant communities living on contaminated sites might be suitable accumulation bioindicators.

360 Results presented in this study illustrate that analysis of the ensemble of vegetation as a whole indeed clearly differentiated the studied sites and provided a characteristic fingerprint of metal bioavailability.

It must be kept in mind that such an evaluation of bioavailability gives information about real field situations, i.e the equilibrium state between the abiotic and biotic compartments at a given time. Consequently any modification of one or the other of these compartments, either due to natural changes or for site redevelopment purposes, can alter the bioavailability of metals and thus, their fate in the environment, in such a way that cannot be anticipated.

Also, it is obvious that the accuracy of the results is closely dependent on the choice of 
the "Reference Plant". In this work we used the data of Markert (1992) but in a risk assessment procedure these values could be revisited at a country or even regional scale. Whatever the reference value is, our results show that the analyses of plant communities, in terms of metal contents, could be a useful additional tool to complete soil chemical analyses, to more accurately evaluate metal bioavailability.

Evidently, the small number and types of sites studied, means that an expansion of this approach to other areas and differing polluted sites is an excellent path for further research. Another question that merits examining, concerns the respective effects of soil ageing and successional changes in plant communities, in the decrease (or increase) in the bioavailability of metals on vegetated contaminated sites.

\section{Acknowledgements}

The authors wish to thank Chris Yukna for his help with proofreading. We also gratefully acknowledge financial support from Région Rhône-Alpes («AVENIR » program) and from the "Agence pour le Développement et la Maîtrise de l'Energie" (ADEME, "Bioindicators" I

385 program). Cécile Grand (ADEME) and Antonio Bispo (ADEME) are particularly appreciated. We also thank Bruno Cornier and Jacqueline Jolly for their kind assistance in botanical surveys of studied sites.

\section{References}

390 Adriano, D.C. (2001). Trace elements in terrestrial environments: biogeochemistry, bioavailability and risks of metals, Springer-Verlag, New York, Berlin, Heidelberg, 884pp.

AFNOR (1994). Soil quality - Extraction des éléments en traces solubles dans l'eau régale Norme française NF ISO 11466. 
AFNOR (2001). Soil quality - Dissolution for the determination of total element contents -

Part 1: dissolution with hydrofluoric and perchloric acids - French standard NF ISO $14869-1$

AFNOR (2002). Soil quality - Dissolution for the determination of total element content - Part 2 : dissolution by alkaline fusion - International standard ISO 14869-2:2002.

AFNOR (2003). Soil quality - Determination of copper, manganese and zinc contents Extraction by means of ammonium acetate in presence of EDTA - French standard NF X 31-120.

AFNOR (2005). Soil quality - Determination of pH - French standard NF ISO 10390.

AFNOR (2008). Soil quality - Requirements and guidance for the selection and application of methods for the assessment of bioavailability of contaminants in soil and soil materials. International Standard ISO 17402:2008.

Aksoy, A., Hale, W.H.G., Dixon, J.M. (1999). Capsella bursa-pastoris (L.) Medic. as a biomonitor of heavy metals. The Science of the Total Environment, 226, 177-186.

Antonovics, J., Bradshaw, A.D., Turner, R.G. (1971). Heavy metal tolerance in plants. Advances in Ecological Research, 7, 1-85.

Baker, A.J.M. (1987). Metal tolerance. New Phytologist, 106, 93-111.

Baize, D. (2000). Teneurs totales en "métaux lourds" dans les sols français - Résultats du programme ASPITET. Courrier de l'Environnement de l'INRA, 39, 39-54.

Baker, A.J.M. (1981). Accumulators and excluders - Strategies in the response of plants to heavy metals. Journal of Plant Nutrition, 3, 643-654.

Beckett, P.H.T. (1989). The use of extractants in studies on trace metals in soils, sewage sludges, and sludge-treated soils, in: B.A. Stewart (Ed.), Advances in Soil Science, 9. Springer-Verlag, New York, pp. 143-176.

Broadley, M.A., Willey, N.J., Wilkins, J.C., Baker, A.J.M., Mead, A., White, P.J. (2001). 
Phylogenetic variation in heavy metal accumulation in angiosperms. New Phytologist, $152,9-27$.

Duvigneaud, P., Denayear-de Smet, S. (1970). Phytogéochimie des groupes écosociologiques forestiers de Haute Belgique. Oecologia Plantarum, 5, 1-32.

Fairbrother, A., Wenstel, R., Sappington, K., Wood, W. (2007). Framework for metals risk assessment. Ecotoxicology \& Environmental Safety, 68, 145-227.

Gomot de Vaufleury, A., Pihan, F. (2000). Growing snails used as sentinels to evaluate terrestrial environment contamination by trace elements. Chemosphere, 40, 275-284.

Harada, H., Hatanaka, T. (2000). Natural background levels of trace elements in wild plants: variation and distribution in plant species. Soil Science \& Plant Nutrition, 46, 117-125.

430 Harmsen, J. (2007). Measuring bioavailability: from a scientific approach to standard methods. Journal of Environmental quality, 36, 1420-1428.

Hodson, M.E., Vijver, M.G., Peijnenburg, W.J.G.M. (2011). Bioavailability in soils. In FA Swartjes (Ed.), Dealing with contaminated sites: from theory toward practical application. Springer. pp 721-747.

435 Höhne, H. (1962) Vergleichende untersuchungen über mineralstoff- und stickstoffgehalt sowie trockensubstanzproduktion von waldbodenpflanzen. Archives Forstwiss, 11, 10851141.

Houba, V.J.G., Lexmond, T.M., Novozamsky, I., van der Lee, J.J. (1996). State of the art and future developments in soil analysis for bioavailability assessment. The Science of the Total Environment, 178, 21-28.

Houba, V.J.G., Novozamski, I., Lexmond, T.H.M., Van Der Lee, J.J. (1990). Applicability of $0.01 \mathrm{M} \mathrm{CaCl}_{2}$ as a single extractant for the assessment of the nutrient status of soils and other diagnostic purposes. Communication in Soil Sciences \& Plant Analyse, 21, 22812291. 
445 Kuleff, I., Djingova, R. (1984). The dandelion (Taraxacum officinale) - A monitor for environmental pollution? Water, Air \& Soil Pollution, 21, 77-85.

Lanno, R., Wells, J., Conder, J., Bradham, K., Basta, N. (2004). The bioavailability of chemicals in soil for earthworms. Ecotoxicology \& Environmental Safety, 57, 39-47.

Le Guédard, M., Faure, O., Bessoule, J-J. (2012). Early changes in the fatty acid composition of photosynthetic membrane lipids from Populus nigra grown on a metallurgic landfill. Chemosphere, 88, 693-698.

Lindsay, W.L., Norvell, W.A. (1978). Development of a DTPA soil test for zinc, manganese and copper. Soil Science Society of America Journal, 42, 421-428.

Lopes, C., Herva, M., Franco-Uria, A, Roca, E. (2012). Multicorrelation models and uptake factors to estimate metal concentrations from soil and metal in plants in pasturelands fertilized with manure. Environmental Pollution, 166, 17-22.

Macnair, M.R. (1993). The genetics of metal tolerance in vascular plants. New phytologist, $124,541-559$.

Madejon, P., Maranon, T., Murillo, J.M., Robinson, B. (2004). White poplar (Populus alba) as a biomonitor of trace elements in contaminated riparian forests. Environmental Pollution, 132, 145-155.

Markert, B. (1992). Establishing of "reference plant" for inorganic characterization of different plant species by chemical fingerprint. Water, Air \& Soil Pollution, 64, 533-538.

McLaughlin, M.J., Zarcinas, B.A., Stevens, D.P., Cook, N. (2000). Soil testing for heavy metals. Communication in Soil Sciences \& Plant Analyse, 31, 1661-1700.

Mertens, J., Luyssaert, S., Verheyen, K. (2005). Use and abuse of trace metal concentrations in plant tissue for biomonitoring and phytoextraction. Environmental Pollution, 138, 1-4. Moreno-Jiménez, E., Beesley, L., Lepp, N.W., Dickinson, N.M., Hartley, W., Clemente, R. (2011). Field sampling of pore water to evaluate trace element mobility and associated 
environmental risk. Environmental Pollution, 159, 3078-3085.

Mourier, B., Fritsch, C., Dhivert, E., Gimbert, F., Coeurdassier, M., Pauget, B., de Vaufleury, A., Scheifler, R. (2011). Chemical extractions and predicted free ion activities fail to estimate metal transfer from soil to field land snails. Chemosphere, 85, 1057-1065.

Murphy, A.P., Coudert, M., Barker, J. (2000). Plants as biomarkers for monitoring heavy metal contaminants on landfill sites using sequential extraction and inductively coupled plasma atomic emission spectrophotometry (ICP-AES). Journal of Environmental Monitoring, 2, 621-627.

Nahami, J., Hodson, M.E., Black, S. (2007). A review of studies performed to assess metal uptake by earthworms. Environmental Pollution, 145, 402-424.

480 Nursita, A.I., Singh, B., Lees, E. (2009). Cadmium bioaccumulation in Proisotoma minuta in relation to bioavailability in soils. Ecotoxicology and Environmental safety, 72, 17671773.

Peijnenburg, W.J.G.M., Posthuma, L., Eijsackers, H.J.P., Allen, H.E. (1997). A conceptual framework for implementation of bioavailability of metals for environmental management purposes. Ecotoxicology and Environmental safety, 37, 163-172.

Pérès, G., Vandenbulcke, F., Guernion, M., Hedde, M., Beguiristain, T., Douay, F., Houot, S., Piron, D., Richard, A., Bispo, A., Grand, C., Galsomies, L., Cluzeau, D. (2011). Earthworm indicators as tools for soil monitoring, characterization and risk assessment. An example from the national Bioindicator programme (France). Pedobiologia, 54, Supplement, S77-S87.

Quevauviller, P., Rauret, G., Lopez-Sanchez, J.F., Rubio, R., Ure, A., Muntau, H. (1997). Certification of trace metal extractable contents in a sediment reference material (CRM 601) following a three step sequential extraction procedure. The Science of the Total Environment, 205, 223-234. 
R Development Core Team (2010). A language and Environment for Statistical Computing. R Foundation for Statistical Computing, Vienna, Austria.

Remon, E., Bouchardon, J-L., Faure, O. (2007). Multi-tolerance to heavy metals in Plantago arenaria Waldst. \& Kit.: adaptative versus constitutive characters. Chemosphere, 69, 4147.

500 Remon, E., Bouchardon, J-L., Cornier, B., Guy, B., Leclerc, J-C., Faure, O. (2005). Soil characteristics, heavy metal availability and vegetation recovery at a former metallurgical landfill: implications in risk assessment and site restoration. Environmental Pollution, $137,316-323$.

Semple, K., Doick, K.J., Jones, K.C., Burauel, P., Craven, A., Harms, H. (2004). Defining bioavailability and bioaccessibility of contaminated soil and sediment is complicated. Environmental Science and Technology, 38, 228A-231A.

Scheckel, K.G., Chaney, R., Basta, N.Y., Ryan, J.A. (2009). Advances in assessing bioavailability of metal(loid)s in contaminated soils. In Advances in Agronomy, vol. 104. D.L. Sparks Ed., Academic Press, pp. 1-52

510 Simon, L., Martin, H.W., Adriano, D.C. (1996). Chicory (Cichorium intybus L.) and dandelion (Taraxacum officinale Web.) as phytoindicators of cadmium contamination. Water, Air \& Soil Pollution, 91, 351-362.

Tessier, A., Campbell, P.G.C., Bisson, M. (1989). Sequential extraction procedure for the speciation of particulate trace metals. Analytical Chemistry, 51, 844-851.

515 Ure, A.M. (1996). Single extraction schemes for soil analysis and related applications. The Science of the Total Environment, 178, 3-10.

Van Gestel, C.A.M. (2008). Physico-chemical and biological parameters determine metal bioavailability in soils. Science of the Total Environment, 406, 385-395.

Viro, P.J. (1955). Use of ethylenediamnetetraacetic acid in soil analysis. I: Experimental. Soil 
Science, 79, 459-465.

Wang, J., Zhang, C.B., Ke, S.S., Qian, B.Y. (2011). Different spontaneous plant communities in Sanmen $\mathrm{Pb} / \mathrm{Zn}$ mine tailing and their effects on mine tailing physico-chemical properties. Environmental Earth Sciences, 62, 779-786.

Wilson, B., Pyatt, B., Denton, G. (2009). An evaluation of the bioavailability and bioaccumulation of selected metals occurring in a wetland area on the volcanic island of Guam, Western Pacific Ocean. Journal of Environmental Sciences, 21, 1547-1551.

Zarcinas, B.A., Cartwright, B., Spouncer, L.R. (1987). Nitric acid digestion and multi-element analysis of plant material by inductively coupled plasma spectrometry. Communication in Soil Sciences \& Plant Analyse, 18, 131-146. 
Table I: selected species representative of the plant communities collected on the three metallurgical landfills (Dor, Lay and Usi) and on the control uncontaminated site (Nat). 0 or 1 indicates presence or absence.

\begin{tabular}{|c|c|c|c|c|c|c|}
\hline \multirow{2}{*}{ Species } & \multirow{2}{*}{ Familly } & \multirow{2}{*}{ Code name* } & \multicolumn{4}{|c|}{ Site } \\
\hline & & & Dor & Lay & Usi & Nat \\
\hline Acer platanoides & Aceraceae & ACPL & 1 & 1 & 0 & 0 \\
\hline Acer pseudoplatanus & Aceraceae & ACPS & 0 & 0 & 0 & 1 \\
\hline Ailanthus altissima & Simaroubaceae & AIAL & 0 & 0 & 1 & 0 \\
\hline Artemisia campestris & Asteraceae & ARCA & 0 & 1 & 0 & 0 \\
\hline Chelidonium majus & Papaveraceae & CHMA & 1 & 0 & 0 & 0 \\
\hline Clematis vitalba & Ranunculaceae & CLVI & 1 & 0 & 0 & 0 \\
\hline Cornus sanguinea & Cornaceae & COSA & 0 & 1 & 0 & 0 \\
\hline Crataegus monogyna & Rosaceae & CRMO & 0 & 1 & 0 & 1 \\
\hline Elytrigia campestris & Poaceae & ELCA & 0 & 1 & 0 & 0 \\
\hline Galium aparine & Rubiaceae & GAAP & 0 & 1 & 0 & 0 \\
\hline Geranium pyrenaicum & Geraniaceae & GEPY & 1 & 0 & 0 & 0 \\
\hline Hedera helix & Araliaceae & HEHE & 1 & 0 & 0 & 1 \\
\hline Lactuca serriola & Asteraceae & LASE & 0 & 0 & 0 & 1 \\
\hline Lactuca virosa & Asteraceae & LAVI & 0 & 0 & 1 & 0 \\
\hline Melilotus albus & Fabaceae & MEAL & 0 & 1 & 1 & 0 \\
\hline Oenothera biennis & Onagraceae & OEBI & 0 & 0 & 1 & 0 \\
\hline Plantago arenaria & Plantaginaceae & PLAR & 0 & 0 & 1 & 0 \\
\hline Populus nigra & Salicaceae & PONI & 0 & 0 & 1 & 0 \\
\hline Reseda lutea & Resedaceae & RELU & 0 & 0 & 1 & 0 \\
\hline Robinia pseudoacacia & Fabaceae & ROPS & 1 & 1 & 0 & 1 \\
\hline Rubus sp. & Rosaceae & RUSP & 1 & 1 & 0 & 1 \\
\hline Scrophularia canina & Scrophulariaceae & SCCA & 0 & 0 & 1 & 0 \\
\hline Taxus baccata & Taxaceae & TABA & 1 & 0 & 0 & 0 \\
\hline Teucrium scorodania & Lamiaceae & TESC & 0 & 0 & 0 & 1 \\
\hline Urtica dioica & Urticaceae & URDI & 0 & 0 & 0 & 1 \\
\hline Verbascum densiflorum & Scrophulariaceae & VEDE & 0 & 0 & 1 & 0 \\
\hline Vicia sativa & Fabaceae & VISA & 0 & 1 & 0 & 0 \\
\hline
\end{tabular}

*Code names refer to Figure 1. 
Table II: $\mathrm{pH}$ and "pseudo-total" metal contents (extracted with aqua regia) in soils from three metallurgical landfills (Dor, Lay and Usi) and one control uncontaminated site (Nat). $n=12$, $\mathrm{n}=15, \mathrm{n}=19$ and $\mathrm{n}=3$ for Dor, Lay, Usi and Nat, respectively. Metal contents are in mg.kg ${ }^{-1}$ DW.

\begin{tabular}{|c|c|c|c|c|c|c|c|c|}
\hline Site & $\begin{array}{c}\text { Distribution } \\
\text { parameter }\end{array}$ & $\mathrm{pH}$ & $\mathrm{Cd}$ & $\mathrm{Cr}$ & $\mathrm{Cu}$ & $\mathrm{Ni}$ & $\mathrm{Pb}$ & $\mathrm{Zn}$ \\
\hline \multirow{4}{*}{ Dor } & $10^{\text {th }}$ centile & 7.1 & bdl & 292 & 52 & 144 & 23 & 46 \\
\hline & Median & $8.3^{\mathrm{a}}$ & $0.3^{\mathrm{a}}$ & $1623^{a}$ & $208^{a}$ & $1357^{\mathrm{a}}$ & $178^{\mathrm{a}, \mathrm{b}}$ & $298^{a, b}$ \\
\hline & $90^{\text {th }}$ centile & 8.5 & 71.2 & 7221 & 1120 & 5146 & 3159 & 9222 \\
\hline & MAD & 0.4 & 0.5 & 1937 & 230 & 1704 & 224 & 315 \\
\hline \multirow{4}{*}{ Lay } & $10^{\text {th }}$ centile & 7.7 & bdl & 106 & 59 & 68 & 171 & 78 \\
\hline & Median & $7.9^{\mathrm{a}}$ & bdl & $305^{b}$ & $158^{a}$ & $260^{b}$ & $581^{\mathrm{a}}$ & $206^{a}$ \\
\hline & $90^{\text {th }}$ centile & 8.1 & 2.2 & 662 & 203 & 503 & 1513 & 394 \\
\hline & MAD & 0.2 & 0.0 & 225 & 61 & 219 & 606 & 128 \\
\hline \multirow{4}{*}{ Usi } & $10^{\text {th }}$ centile & 7.7 & 6.7 & 530 & 149 & 327 & 71 & 139 \\
\hline & Median & $8.1^{\mathrm{a}}$ & $14.0^{b}$ & $1392^{\mathrm{a}}$ & $\mathbf{5 0 2}^{\mathrm{b}}$ & $755^{a}$ & $601^{\mathrm{a}}$ & $1152^{b}$ \\
\hline & $90^{\text {th }}$ centile & 8.8 & 83.7 & 3900 & 1602 & 1705 & 12018 & 7740 \\
\hline & MAD & 0.4 & 10.3 & 1171 & 321 & 460 & 657 & 1440 \\
\hline \multirow{4}{*}{ Nat } & $10^{\text {th }}$ centile & 3.9 & 0.2 & 31 & 19 & 17 & 38 & 103 \\
\hline & Median & $3.9^{b}$ & $0.2^{\mathrm{a}}$ & $3^{\mathrm{c}}$ & $19^{c}$ & $19^{c}$ & $39^{b}$ & $108^{\mathrm{a}}$ \\
\hline & $90^{\text {th }}$ centile & 4.1 & 0.4 & 34 & 19 & 19 & 39 & 110 \\
\hline & MAD & 0.0 & 0.0 & 2 & 0 & 0 & 1 & 3 \\
\hline
\end{tabular}

*In a given column, values followed by the same letters are not significantly different at $\mathrm{p}<0.05$ 
545 Table III: "potentially available" metal contents (extracted with ammonium acetate-EDTA) in soils from three metallurgical landfills (Lay, Dor and Usi) and one control uncontaminated site (Nat). $n=12, n=15, n=19$ and $n=3$ for Dor, Lay, Usi and Nat, respectively. Metal contents are in mg.kg ${ }^{-1} \mathrm{DW}$.

\begin{tabular}{|c|c|c|c|c|c|c|c|}
\hline Site & $\begin{array}{c}\text { Distribution } \\
\text { parameter }\end{array}$ & $\mathrm{Cd}$ & $\mathrm{Cr}$ & $\mathrm{Cu}$ & $\mathrm{Ni}$ & $\mathrm{Pb}$ & $\mathrm{Zn}$ \\
\hline \multirow{4}{*}{ Dor } & $10^{\text {th }}$ centile & 0.07 & 0.08 & 13.6 & 4.1 & 0 & 16 \\
\hline & Median & $0.20^{\mathrm{a}, \mathrm{b}}$ & $0.97^{\mathrm{a}}$ & $25.4^{\mathrm{a}}$ & $8.7^{\mathrm{a}}$ & $9^{a}$ & $30^{\mathrm{a}, \mathrm{b}}$ \\
\hline & $90^{\text {th }}$ centile & 29.67 & 3.95 & 101.8 & 48.9 & 75 & 706 \\
\hline & MAD & 0.16 & 0.64 & 16.7 & 9.2 & 14 & 29 \\
\hline \multirow{4}{*}{ Lay } & $10^{\text {th }}$ centile & 0.01 & 0.02 & 11.7 & 1.5 & 46 & 10 \\
\hline & Median & $0.22^{\mathrm{a}}$ & $0.02^{b}$ & $29.5^{\mathrm{a}}$ & $3.6^{b}$ & $298^{b}$ & $20^{a}$ \\
\hline & $90^{\text {th }}$ centile & 0.33 & 0.51 & 37.3 & 6.0 & 1248 & 53 \\
\hline & MAD & 0.07 & 0.00 & 7.3 & 2.3 & 328 & 11 \\
\hline \multirow{4}{*}{ Usi } & $10^{\text {th }}$ centile & 0.10 & 0.19 & 10.6 & 1.6 & 11 & 6 \\
\hline & Median & $0.58^{b}$ & $0.26^{\mathrm{a}}$ & $39.2^{\mathrm{a}}$ & $4.3^{\mathrm{a}, \mathrm{b}}$ & $109^{b, c}$ & $156^{b}$ \\
\hline & $90^{\text {th }}$ centile & 11.30 & 1.13 & 86.0 & 12.7 & 2684 & 544 \\
\hline & MAD & 0.64 & 0.09 & 35.3 & 4.4 & 80 & 166 \\
\hline \multirow{4}{*}{ Nat } & $10^{\text {th }}$ centile & 0.11 & 0.40 & 3.7 & 1.2 & 14 & 5 \\
\hline & Median & $0.12^{a, b}$ & $0.46^{\mathrm{a}, \mathrm{b}}$ & $3.8^{b}$ & $1.4^{\mathrm{a}, \mathrm{b}}$ & $16^{\mathrm{a}, \mathrm{c}}$ & $6^{c}$ \\
\hline & $90^{\text {th }}$ centile & 0.15 & 0.52 & 4.1 & 1.9 & 22 & 6 \\
\hline & MAD & 0.01 & 0.10 & 0.1 & 0.3 & 3 & 1 \\
\hline
\end{tabular}

$550 *$ In a given column, values followed by the same letters are not significantly different at $\mathrm{p}<0.05$ 
Table IV: Metal contents in leaves of plant species representative of communities grown on three metallurgical landfills (Lay, Dor and Usi) and one control uncontaminated site (Nat). Number of representative species were 8 (Dor), 10 (Lay), 9 (Usi) and 8 (Nat). Number of leaf 560 samples were $n=80, n=100, n=88$ and $n=48$ for Dor, Lay, Usi and Nat, respectively. Metal contents are in mg.kg-1 $\mathrm{DW}$.

\begin{tabular}{|c|c|c|c|c|c|c|c|}
\hline Site & $\begin{array}{c}\text { Distribution } \\
\text { parameter }\end{array}$ & $\mathrm{Cd}$ & $\mathrm{Cr}$ & $\mathrm{Cu}$ & $\mathrm{Ni}$ & $\mathrm{Pb}$ & $\mathrm{Zn}$ \\
\hline \multirow{4}{*}{ Dor } & $10^{\text {th }}$ centile & 0.04 & 0.22 & 1.72 & 0.63 & bdl & 11.76 \\
\hline & Median & $0.07^{\mathrm{a}}$ & $0.70^{\mathrm{a}}$ & $3.31^{\mathrm{a}}$ & $1.91^{\mathrm{a}}$ & $0.07^{\mathrm{a}}$ & $23.59^{a}$ \\
\hline & $90^{\text {th }}$ centile & 0.33 & 2.29 & 6.19 & 10.99 & 0.26 & 59.40 \\
\hline & MAD & 0.03 & 0.47 & 1.54 & 1.73 & 0.11 & 11.43 \\
\hline \multirow{4}{*}{ Lay } & $10^{\text {th }}$ centile & 0.04 & 0.30 & 1.70 & 0.23 & bdl & 11.64 \\
\hline & Median & $0.06^{b}$ & $1.07^{b}$ & $3.64^{a}$ & $0.72^{b}$ & $0.12^{b}$ & $20.22^{b}$ \\
\hline & $90^{\text {th }}$ centile & 0.16 & 4.03 & 6.83 & 3.30 & 0.87 & 31.64 \\
\hline & MAD & 0.02 & 0.98 & 1.54 & 0.68 & 0.15 & 9.93 \\
\hline \multirow{4}{*}{ Usi } & $10^{\text {th }}$ centile & 0.00 & 0.52 & 7.44 & 1.49 & bdl & 32.38 \\
\hline & Median & $0.15^{\mathrm{c}}$ & $1.83^{c}$ & $11.84^{b}$ & $9.75^{c}$ & $1.27^{\mathrm{c}}$ & $62.40^{c}$ \\
\hline & $90^{\text {th }}$ centile & 0.62 & 8.00 & 20.15 & 60.84 & 3.81 & 427.12 \\
\hline & MAD & 0.14 & 1.62 & 4.17 & 12.36 & 1.16 & 44.63 \\
\hline \multirow{4}{*}{ Nat } & $10^{\text {th }}$ centile & 0.06 & 0.12 & 6.13 & 0.88 & 0.31 & 19.82 \\
\hline & Median & $0.12^{c}$ & $0.22^{d}$ & $9.20^{c}$ & $1.80^{\mathrm{a}}$ & $0.53^{d}$ & $41.70^{d}$ \\
\hline & $90^{\text {th }}$ centile & 1.76 & 0.37 & 13.42 & 4.03 & 0.66 & 116.60 \\
\hline & MAD & 0.09 & 0.10 & 2.34 & 1.23 & 0.13 & 30.79 \\
\hline
\end{tabular}

*In a given column, values followed by the same letters are not significantly different at $\mathrm{p}<0.05$ 


\section{Figure caption}
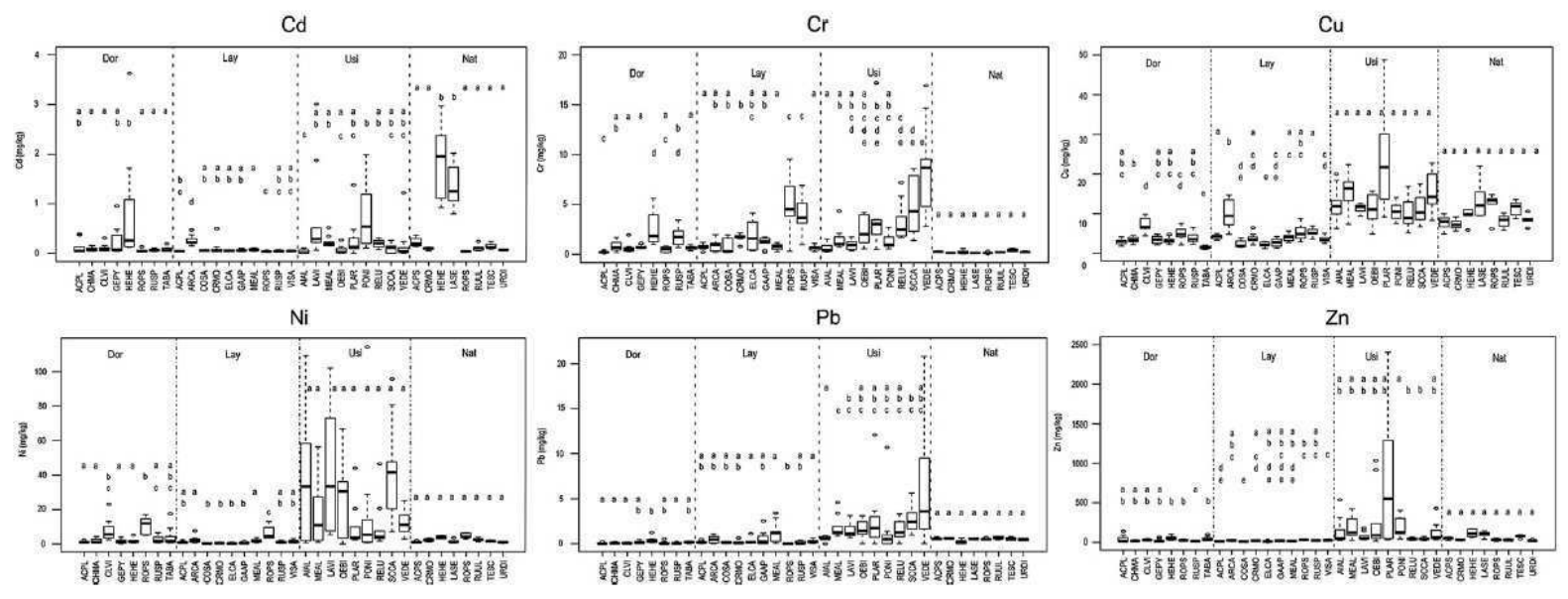

Figure 1: Distribution of metal content in the vegetation of three metallurgical sites (Lay,

Dor, Usi) and one control uncontaminated site (Nat). Measured were performed on leaves taken from the 8 to 10 most abundant species of each site, 10 individuals were sampled for each species. For each site, values with the same letter are not significantly different at $\mathrm{p}=0.05$. For code names, see Table I.

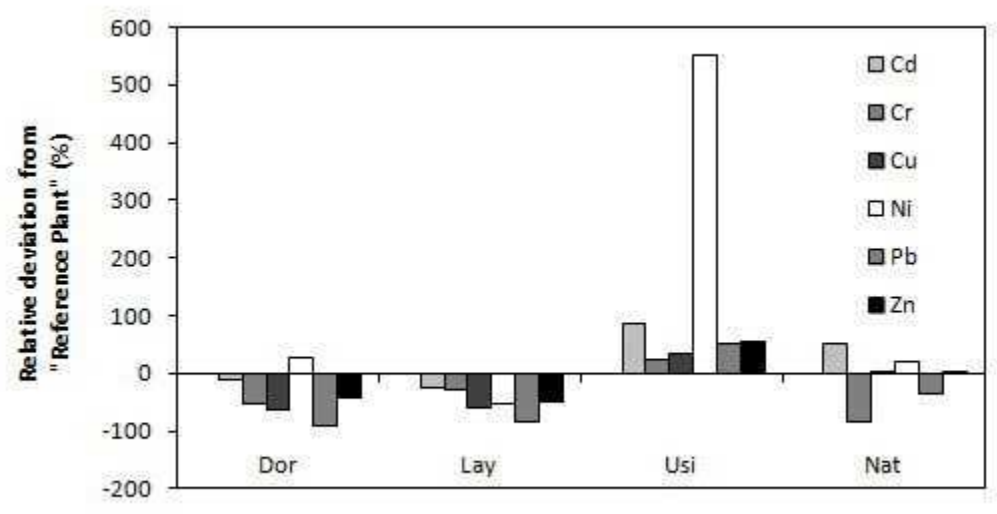

Figure 2: Fingerprints of metals contents of plant communities from three metallurgical landfills (Lay, Dor and Usi) and one control natural site (Nat). Results expressed as relative deviation from the "Reference Plant" of Markert (1992). 